\title{
Upaya Meningkatkan Prestasi Belajar Siswa Matematika Melalui Strategi Pembelajaran Tutor Sebaya Dalam Penguasaan Bangun Datar Kelas VI SD Hidayatur Rohman Surabaya
}

\author{
Denok Julianingsih
}

\author{
STKIP Bina Insan Mandiri Surabaya \\ email: denok451@gmail.com
}

\begin{abstract}
The problem that existed in the sixth grade students at SD Hidayatur Rohman is that there are any students who consider that the math lesson is an elusive lesson. If the student does not understand the lessons in the class, the student does not want to ask the teacher or even feel ashamed and afraid on the teacher. For that need to apply learning strategies that can help students who experience psychological problems that is with peer tutoring strategy. The purpose of this research is to make the achievement of learning mathematics which can be increased through peer tutor learning strategy in two dimensional subject. The method used in this research is the method of documentation, test method, and observation. While data analysis techniques using test of student learning outcomes, analysis mastery learning, analysis of students and teachers' observation sheet, and analysis of learning outcomes increasing. The subject of this research is the students of grade VI SD Hidayatur Rohman Surabaya. From the results of data analysis and conclusion then obtained the results of the test in the first cycle with an average score of 58.85 students while the average average at the end of the second cycle of 74.47 billion of $26.54 \%$. This learning is done with the completeness of student learning outcomes in the classical $80.95 \%$ is very feasible $47.62 \%$ above the predetermined indicator, which is equal to $75 \%$. While the percentage of students activeness in the classical as much as $80,95 \%$ and activeness of teacher equal to $91,25 \%$ can be used in learning cycle II can increase according to indicator which have been determined.
\end{abstract}

\section{Keywords: Peer Tutoring Strategy, Two Dimensional}

\begin{abstract}
Abstrak. Permasalahan yang terdapat pada siswa kelas VI di SD Hidayatur Rohman adalah masih banyaknya siswa yang menganggap bahwa pelajaran matematika adalah pelajaran yang sukar dipahami. Jika siswa tidak paham dengan pembelajaran yang dilakukan guru di kelas siswa tidak mau untuk bertanya kepada guru atau bahkan merasa malu dan takut kepada gurunya. Untuk itu perlu diterapkan strategi pembelajaran yang dapat membantu siswa yang mengalami masalah psikologi yaitu dengan strategi pembelajaran tutor sebaya. Tujuan dari penelitian ini adalah untuk menunjukkan bahwa prestasi belajar matematika siswa dapat meningkat melalui strategi pembelajaran tutor sebaya dalam pokok bahasan bangun datar. Metode yang digunakan dalam penelitian ini adalah metode dokumentasi, metode tes, dan metode observasi (pengamatan). Sedangkan teknik analisa data dengan menggunakan analisis hasil belajar siswa, analisis ketuntasan belajar, analisis lembar pengamatan guru dan siswa, dan analisis peningkatan hasil belajar. Subyek dari penelitian ini adalah siswa kelas VI SD Hidayatur Rohman Surabaya. Dari hasil analisis data dan simpulan maka diperoleh hasil ujian pada siklus I dengan nilai rata-rata siswa sebesar 58,85 sedangkan nilai rata-rata pada akhir siklus II sebesar 74,47 sehingga mengalami peningkatan sebesar 26,54\%. Pembelajaran dalamhal ini dikatakan berhasil karena ketuntasan hasil belajar siswa secara klasikal sebesar 80,95\% yang artinya mengalami peningkatan sebesar $47,62 \%$ diatas indikator yang sudah ditetapkan, yaitu sebesar $75 \%$. Sedangkan prosentase keaktifan siswa secara klasikal sebesar $80,95 \%$ dan keaktifan guru sebesar 91,25\% sehingga dapat dikatakanhasil belajar pada pembelajaran siklus II dapat meningkat sesuai dengan indikator yang sudah ditetapkan.
\end{abstract}

Kata kunci: Strategi Tutor Sebaya, Bangun Datar 


\section{PENDAHULUAN}

Suatu lembaga pendidikan yaitu sekolah, selalu mengharapkan proses pendidikan yang dapat menghasilkan kualitas yang benar-benar sesuai dengan apa yang telah ditetapkan. Terciptanya lulusan peserta didik di sekolah yang dapat memenuhi kebutuhan masyarakat sangat dipengaruhi dari berbagai faktor misalnya kompetensi guru dan kemampuan siswa. Selain itu strategi pembelajaran yang digunakan oleh guru sangat berpengaruh dan berperan penting dalam membentuk kualitas individu siswa dalam pemerolehan kompetensi yang dibutuhkan.

Berdasarkan hasil wawancara dari beberapa siswa SD Hidayatur Rohman Surabaya pada tanggal 12 November 2016, Pkl 08.45 WIBmasih banyak siswa yang beranggapan sama, bahwa mata pelajaran matematika adalah mata pelajaran yang sukar dipahami, bersifat abstrak dan menjemukan. Sehingga hasil belajar siswa kurang memuaskan. Hal ini dapat didukung oleh hasil rekapan nilai UTS kelas VI semester 1 sebanyak 21 siswa. Oleh karena itu guru perlu mengusahakan pembelajaran yang lebih menarik dan mempunyai peranan yang cukup besar untuk mengatasi permasalahan yang sering dihadapi siswa.

Berdasarkan hal itu maka tugas guru bukanlah memberikan pengetahuan saja, melainkan menyiapkan situasi yang memotivasi anak untuk bertanya, mengamati, mengadakan eksperimen, serta menemukan fakta dan konsep sendiri. Dilain pihak, umumnya jumlah siswa pada suatu kelas relatif banyak dan kurangnya alat pelajaran. Sedangkan siswa perlu mendapat kesempatan untuk bekerja dalam kelompok serta memperoleh umpan balik padahal waktu guru terbatas.

Permasalahan inilah yang terjadi di SD Hidayatur Rohman Surabaya. Hal ini dapat diketahui dari hasil wawancara dengan beberapa siswa kelas VI yang mengungkapkan beberapa informasi antara lain banyak siswa yang sudah menganggap matematika sulit dahulu; bila siswa tidak bisa saat pembelajaran di kelas, siswa takut dan malu untuk bertanya; dan kebanyakan siswa hanya belajar bila ada PR atau ulangan, bahkan seringkali beberapa siswa mengerjakan PR di sekolahan dengan menyontek temannya.

Berdasarkan permasalahan diatas dan dengan melihat kenyataan sehari-hari yang sering terjadi dalam proses belajar mengajar di SD Hidayatur Rohman Surabaya pada saat istirahat, yaitu:

1. Dalam proses belajar mengajar siswa mau bertanya kepada teman sebangkunya secara berbisik, hal ini membuktikan bahwa siswa malu, tidak berani bertanya kepada guru, tetapi tidak malu untuk bertanya kepada teman;

2. Pada saat istirahat siswa lebih banyak yang bergerombol, bercengkrama dan bertukar pikiran dari pada yang sendirian, hal ini menunjukkan bahwa sebenarnya banyak siswa lebih suka bergerombol dari pada sendirian.

Berkaitan dengan hal itu, ada beberapa hal yang perlu mendapatkan perhatian bagi para guru, dalam kegiatan belajar mengajar, guru dan anak didik terlibat dalam sebuah interaksi dengan bahan pelajaran sebagai mediumnya. Dalam interaksi itu anak didiklah yang lebih aktif, bukan guru. Guru hanya berperan sebagai motivator dan fasilitator (Djamarah dan Zain, 2006:44). Agar proses interaksi tersebut sesuai dengan tujuan yang dikehendaki, maka diperlukan suatu bentuk inovasi baru yang diharapkan mampu mengubah pandangan guru dalam mengelola pembelajaran.

Jika dilihat dari permasalahan tersebut yaitu tidak adanya interaksi antara guru dengan siswa karena siswa merasa malu atau enggan bertanya dengan gurunya pada saat pembelajaran berlangsung maka peneliti mencoba untuk menerapkan strategi pembelajaran dengan bantuan tutor sebaya.

Pembelajaran melalui bantuan tutor sebaya adalah pembelajaran yang dapat dilakukan dengan teman sebaya siswa. Pembelajaran melalui tutor sebaya ini yang lebih aktif adalah siswa bukan gurunya. Siswa yang mempunyai kemampuan akademik yang lebih menonjol diharapkan dapat menyampaikan ilmu kepada teman sebayanya di sekolah. Siswa yang terkadang takut bertanya kepada guru saat pembelajaran matematika berlangsung akan dapat dengan leluasa bertanya kepada teman sebaya yang menjadi tutor sebaya siswa. Dengan teman sebaya tidak ada rasa enggan, rendah diri, malu dan sebagainya untuk bertanya ataupun minta bantuan menurut Longstreth (dalam Suherman, 2001:233). 
Berdasarkan permasalahan yang telah diuraikan diatas, PTK ini mengambil judul tentang "Upaya Meningkatkan Prestasi Belajar Siswa Matematika Melalui Strategi Pembelajaran Tutor Sebaya Dalam Penguasaan Bangun Datar Kelas VI SD Hidayatur Rohman Surabaya".

\section{Kajian Teori}

Piaget (dalam Trianto, 2007:14) mengemukakan bahwa perkembangan kognitif sebagian besar ditentukan oleh manipulasi dan interaksi aktif anak dengan lingkungan. Pengetahuan datang dari tindakan. Piaget yakin bahwa pengalaman-pengalaman fisik dan manipulasi lingkungan penting bagi terjadinya perubahan perkembangan. Sementara itu bahwa interaksi sosial dengan teman sebaya, khususnya berargumentasi dan berdiskusi membantu memperjelas pemikiran yang pada akhirnya memuat pemikiran itu menjadi lebih logis.

Teori perkembangan Piaget mewakili konstruktivisme, yang memandang perkembangan kognitif sebagai suatu proses dimana anak secara aktif membangun sistem makna dan pemahaman realitas melalui pengalaman-pengalaman dan interaksi-interaksi mereka.

Menurut Piaget (dalam Trianto, 2007:16), perkembangan kognitif sebagian besar bergantung kepada seberapa jauh anak aktif memanipulasi dan aktif berinteraksi dengan lingkungannya.

Teori-teori yang sudah dijelaskan oleh Piaget diatas menjelaskan bahwa perkembangan kognitif seorang anak dapat dibangun melalui interaksi-interaksi dengan lingkungannya. Interaksi tersebut dapat dibangun dengan mengatur kegiatan belajar dengan membentuk kelompokkelompok kecil, salah satunya dengan mengoptimalkan pembelajaran dengan menggunakan bantuan teman sendiri (tutor sebaya).

Siswa-siswi di sekolah membentuk suatu lingkungan pergaulan yang dikenal sebagai lingkungan sosial siswa. Dalam lingkungan sosial tersebut ditemukan adanya kedudukan dan peranan tertentu. Dalam kehidupan kesiswaan terjadilah hubungan antar siswa. Tiap siswa dalam lingkungan sosial memiliki kedudukan, peranan, dan tanggung jawab sosial tertentu. Dalam kehidupan tersebut terjadi pergaulan, seperti hubungan sosial tertentu. Dalam kehidupan tersebut terjadi pergaulan, seperti hubungan akrab, kerjasama, kerja berkoperasi, berkompetisi, bersaing, konflik atau persaingan.

Siswa memiliki kedudukan dan peranan yang diakui oleh sesama. Jika seorang siswa diterima, maka siswa dengan mudah menyesuaikan diri dan segera dapat belajar. Sebaliknya, jika siswa ditolak, maka siswa akan merasa tertekan. Dan, setiap guru akan disikapi secara tertentu oleh lingkungan sosial siswa. Sikap positif atau negatif terhadap guru akan berpengaruh pada kewibawaan guru. Akibatnya, bila guru menegakkan kewibawaan maka siswa akan dapat mengelola proses belajar dengan baik. Sebaliknya, bila guru tak berwibawa, maka siswa akan mengalami kesulitan dalam mengelola proses belajar.

Djamarah dan Zein (2010:115) mengatakan bahwa strategi dan penggunaan metode mengajar amat menentukan kualitas hasil belajar mengajar. Seperti yang sudah dijelaskan diatas bahwa seorang siswa yang berada di sekolah menjalin lingkungan sosial siswa, yang terkadang siswa lebih merasa nyaman bergaul dengan sesama teman sendiri jika dibandingkan dengan gurunya. Sehingga strategi dengan menggunakan tutor sebaya diharapkan dapat meningkatkan keberhasilan didalam proses pembelajaran.

Salah satu faktor yang berpengaruh sehingga perlu adanya pembelajaran dengan tutor sebaya adalah faktor psikologis. Kondisi mental anak yang kurang stabil dapat memengaruhi keberhasilan belajar. Sikap mental tersebut misalnya dapat ditunjukkan dengan tidak ada rasa percaya diri kepada siswa untuk bertanya kepada guru. Dari situ pembelajaran dengan bantuan tutor sebaya ini diharapkan dapat membantu masalah-masalah yang dihadapi oleh siswa.

Keberhasilan suatu program pembelajaran tidak disebabkan oleh satu macam sumber daya, tetapi disebabkan oleh perpaduan antara berbagai sumber-sumber daya yang saling mendukung menjadi satu sistem yang integral, Wijaya dan kawan-kawan (dalam Suherman, 2001:233).

Dalam arti luas sumber belajar tidak harus selalu guru. Sumber belajar dapat berasal dari orang lain yang bukan guru, seperti teman dari kelas yang lebih tinggi (kakak kelas), teman sekelas, atau keluarganya di rumah. Sumber belajar bukan guru dan berasal dari orang yang lebih pandai 
disebut tutor Ada dua macam tutor, yaitu tutor sebaya dan tutor kakak. Tutor sebaya adalah teman sebaya yang lebih pandai. Sedangkan tutor kakak adalah tutor dari kelas yang lebih tinggi, Harsunarko (dalam Suherman, 2001:233).

Berdasarkan Zaini dalam (Suyitno, 2004:24) menyatakan bahwa "Metode belajar yang paling baik adalah dengan mengajarkan kepada orang lain. Oleh karena itu, pemilihan model pembelajaran tutor sebaya sebagai strategi pembelajaran akan sangat membantu siswa dalam mengajarkan materi kepada teman-temannya". Sedangkan menurut Miller (dalam Djalil 1997:3.34) berpendapat bahwa "Setiap saat murid memerlukan bantuan dari murid lainnya, dan murid dapat belajar dari murid lainnya".

Diskusi dengan teman sebaya akan membantu menetapkan pola partisipasi dan secara konsekuen, memiliki dampak besar terhadap manajemen kelas. Pembicaraan antara guru dan para siswanya menjadikan banyak ikatan sosial sehingga kelas menjadi hidup Arrends (dalam Trianto, 2007).

Menurut Djamarah dan Zain (2010:27) ada beberapa kesulitan di dalam melaksanakan kegiatan tutoring ini, diantaranya:

1. Siswa yang dibantu sering belajar kurang serius, karena hanya berhadapan dengan kawannya, sehingga hasilnya kurang memuaskan.

2. Ada beberapa anak yang menjadi malu bertanya, karena takut rahasianya diketahui kawannya.

3. Pada kelas-kelas tertentu pekerjaan tutoring ini sukar dilaksankan, karena perbedaan kelamin antara tutor dengan siswa yang diberi program perbaikan.

4. Bagi guru sukar untuk menentukan seorang tutor yang tepat bagi seorang atau beberapa orang siswa yang harus dibimbing.

5. Tidak semua siswa yang pandai atau cepat waktu belajarnya dapat mengerjakannya kembali kepada kawan-kawannya.

Menurut Djamarah dan Zain (2010:27) jika guru menganggap bahwa pekerjaan tutoring dapat dilakukan sebaiknya dilakukan dengan:

1. Siswa yang mengalami kesulitan belajar agak berat (kelompok terberat) dilayani sendiri oleh guru.

2. Siswa yang hanya sedikit mengalami kesulitan (diserahkan kepada tutor).

3. Siswa yang memerlukan kegiatan perbaikan yang kurang berarti (kelompok teringan) diberi tugas untuk mengulangi pelajaran lagi tanpa bantuan siapa pun. Beberapa siswa dari kelompok teringan ini dapat belajar bersama dengan cara mengulang membaca modul untuk memahami bersama.

Kelebihan dan kekurangan strategi pembelajaran tutor sebaya (dalam www.scrib.com) adalah :

1. Kelebihan

(a) Meringankan beban guru dalam membelajarkan siswa, terutama bagi guru yang menghadapi kelas gemuk; (b) Memberikan dampak pengayaan pada siswa menjadi tutornya; (c) Komunikasi antar siswa akan lebih efektif terutama dalam mengatasi beberapa kelemahan guru terutama dalam hubungan komunikasi dengan siswa.

2. Kekurangan

(a) Siswa yang menjadi tutor berpotensi tidak memiliki keahlian membelajarkan; (b) Kelas berpotensi kacau dan tidak terkendali; (c) Guru berpotensi mengabaikan siswa karena terlalu mengandalkan tutor; (d) Akan berpotensi pada perlakuan yang diskriminatif dimana pada keadaan tertentu justru sangat merugikan bagi efektifitas pembelajaran.

Sedangkan cara mengatasi kekurangannya adalah:

1. Guru senantiasa berkeliling sambil membimbing tutor dan siswa.

2. Perhatian guru yang menyeluruh mengawasi siswa agar tidak keluar dari konteks pembicaraan.

3. Pusat perhatian guru adalah menjaga kondusifitas kelas sehingga siswa dapat nyaman belajar dari rekannya. 
Menurut Branley dalam (Suherman, 2001:234) ada tiga cara dasar dalam menyelenggarakan proses pembelajaran dengan tutor, yaitu:

1. Tutor to student adalah pembelajaran yang dalam pelaksanaannya lebih menekankan pada tutor untuk memberikan bimbingan kepada masing-masing teman sehingga ada hubungan timbal balik antara tutor dengan teman (anggota kelompok) yang tidak menjadi tutor dalam kelompok belajar tersebut.

2. Group to tutor adalah pembelajaran yang dalam pelaksanaannya, tutor memberikan arahan/ bimbingan kepada kelompok teman yang kurang pandai.

3. Student to student adalah pembelajaran yang pelaksanaannya dalam kelompok belajar tersebut tutor memberikan bimbingan kepada salah satu teman belajar sedangkan siswa yang satunya dapat memberikan bimbingan kepada teman-teman yang lain.

Dalam penelitian ini peneliti menggunakan tipe tutor to student.

Berikut ini adalah gambar dari ketiga proses pembelajaran diatas:

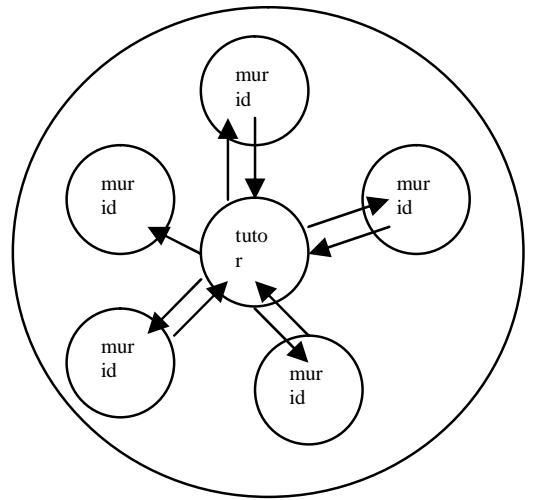

(a)

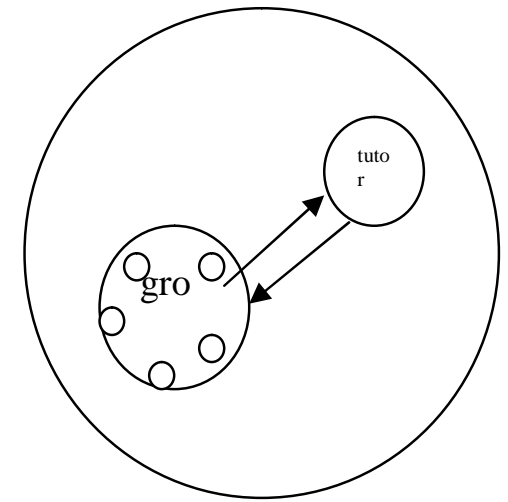

(b)

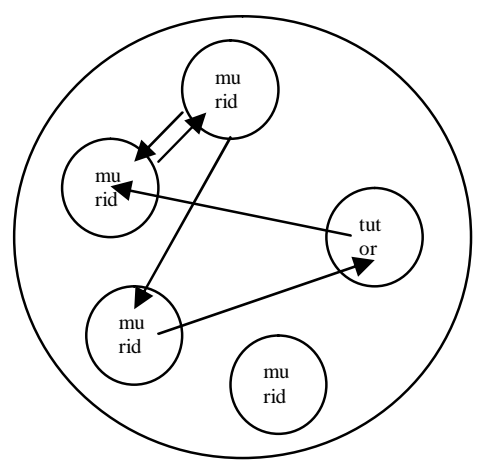

(c)

Gambar 1. (a) Model Operasional Kelompok Tutor to student, (b) Model Operasional Kelompok Group to Tutor, (c) Model Operasional Kelompok Student to Student

Dalam pembelajaran dengan pendekatan tutor sebaya, si tutor hendaknya adalah siswa yang mempunyai kemampuan lebih dibandingkan dengan teman-temanpada umumnya, sehingga pada saat ia memberikan pengayaan atau membimbing teman-temannya tutor sudah menguasai bahan yang akan disampaikan kepada teman-teman lain.

\section{METODE}

PTK ini dirancang dengan metode penelitian deskriptif dengan menggunakan desain khusus yang dijadikan pedoman dalam penelitian ini. Desain yang dijadikan acuan dalam penelitian PTK ini dengan memakai desain dari Lewin (dalam Ekawarna, 2009:15), diantaranya perencanaan (planning), tindakan (acting), pengamatan (observing), dan refleksi (reflecting). 
Hubungan keempat komponen itu dipandang sebagai satu siklus.

\section{Metode Pengumpulan Data}

Data yang dibutuhkan dalam Penelitian Tindakan Kelas (PTK) ini diperoleh dengan menggunakan instrumen dibawah ini :

1. Metode Dokumentasi

Metode dokumentasi adalah metode untuk mengumpulkan data-data hasil belajar siswa sebelumnya, metode ini digunakan untuk mengetahui kemampuan awal siswa sebagai langkah awal dalam pembentukan kelompok belajar dan untuk menentukan tutor sebaya.

2. Metode Tes

Tes digunakan untuk mengetahui hasil belajar siswa kelas VI pada tiap akhir siklus, yang telah diberi perlakuan dengan menggunakan tutor sebaya.

3. Metode Observasi (Pengamatan)

Lembar pengamatan terhadap siswa diperoleh dari hasil mengamati tingkah laku dan kemampuan siswa untuk mendapatkan data tentang perubahan tingkah laku siswa pada saat proses belajar mengajar yang dilakukan oleh guru.

Lembar pengamatan terhadap guru diperoleh dari hasil mengamati kinerja guru untuk mendapatkan data tentang cara kerja, tingkah laku, kemampuan guru saat mengelola proses pembelajaran.

\section{Teknik Analisis Data}

1. Analisis Hasil Belajar Siswa

2. Analisis Ketuntasan Hasil Belajar

$$
\bar{X}=\frac{\sum x}{N}(\text { Arikunto, } 2006: 264)
$$

$$
P \quad e \quad K \quad=\frac{h^{n} \mathrm{nE} \mathrm{n}}{n^{n} \mathrm{nK}} x 100 \% \quad \text { (Supriyanto, 2006) }
$$

3. Analisis Lembar Pengamatan Siswa

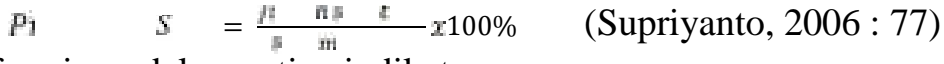

4. Analisis keaktifan siswa dalam setiap indikator:

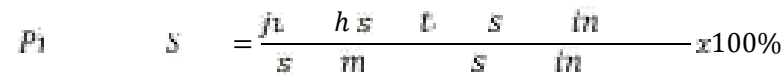

5. Analisis Lembar Pengamatan Guru

$$
P_{1} \quad S \quad=\frac{n^{n} \quad \frac{\pi}{m} \quad t}{m} x 100 \% \quad \text { (Supriyanto, } 2006: 77 \text { ) }
$$

6. Analisis Peningkatan Hasil Belajar Setiap Siklus

7. Indikator Keberhasilan

$$
P=\frac{p-b}{b} x 100 \% \quad \text { (Aqib dkk, } 2008: 53 \text { ) }
$$

Yang menjadi kriteria keberhasilan dalam penelitian ini adalah hasil belajar ketuntasan setiap siswa mencapai nilai $\geq 70$ dalam skala 10-100 dengan prosentase ketuntasan belajar secara klasikal $\geq 75 \%$. Keaktifan setiap siswa tuntas jika prosentase skor keaktifan $\geq 65 \%$ dan prosentase secara klasikal $\geq 65 \%$.

Prosentase keaktifan guru $\geq 75 \%$. 


\section{HASIL DAN PEMBAHASAN}

Berikut ini akan disajikan nilai siswa sebelum Treatment dan setelah treatment.

\begin{tabular}{cccc} 
& \multicolumn{2}{c}{ Tabel $1-$ Nilai Sebelum Treatment } \\
\hline Interval Nilai & Frekuensi & Predikat & Keterangan \\
\hline $88-100$ & 0 & A & Sangat baik \\
\hline $74-87$ & 0 & B & Baik \\
\hline $60-73$ & 3 & C & Cukup \\
\hline$<60$ & 18 & D & Kurang \\
\hline
\end{tabular}

Tabel 2 - Nilai Pada Siklus I

\begin{tabular}{cccc}
\hline Interval Nilai & Frekuensi & Predikat & Keterangan \\
\hline $88-100$ & 0 & A & Sangat baik \\
\hline $74-87$ & 4 & B & Baik \\
\hline $60-73$ & 6 & C & Cukup \\
\hline$<60$ & 11 & D & Kurang \\
\hline
\end{tabular}

Berdasarkan hasil analisis terhadap lembar pengamatan guru pada siklus I diperoleh hasil berikut:

1. Guru sudah baik dalam mempersiapkan kondisi siswa, begitu juga dalam penyampaian materi sehingga muncul respon positif dari siswa, dilihat dari antusias siswa yang bertanya dan menjawab pertanyaan.

2. Guru masih menjadi sumber informasi satu-satunya yang paling dipercaya oleh siswa.

3. Guru dalam memberikan bimbingan kepada tutor sebaya sebesar $80 \%$ yang artinya keaktifan guru dalam membimbing siswa tuntas karena lebih dari $75 \%$.

4. Guru dalam memberikan motivasi kepada tutor sebaya sebesar $80 \%$ yang artinya keaktifan guru dalam memotivasi tutor sebaya tuntas karena lebih dari $75 \%$.

5. Guru dalam memberikan motivasi siswa sebesar $80 \%$ yang artinya keaktifan guru dalam memotivasi siswa tuntas karena lebih dari $75 \%$.

6. Guru dalam memberi apersepsi sebesar $80 \%$ yang artinya keaktifan guru dalam memberi apersepsi tuntas karena lebih dari $75 \%$.

7. Guru mempersiapkan alat peraga dan media sebelum pembelajaran berlangsung sebesar $60 \%$ yang artinya keaktifan guru dalam mempersiapkan alat peraga dan media sebelum pembelajaran berlangsung tidak tuntas karena kurang dari $75 \%$.

8. Guru dalam mengelompokkan siswa masih kurang teratur dengan prosentase sebesar $60 \%$ yang artinya keaktifan guru dalam mengelompokkan siswa tidak tuntas karena kurang dari $75 \%$.

9. Guru masih kurang berperan dalam memotivasi siswa tentang pentingnya kerjasama dalam kelompok yaitu sebesar $60 \%$ yang artinya keaktifan guru dalam dalam memotivasi siswa tentang pentingnya kerjasama dalam kelompok tidak tuntas karena kurang dari $75 \%$.

10.Peran guru sebagai fasilitator sebesar $60 \%$ yang artinya peran guru sebagai fasilitator tidak tuntas karena kurang dari $75 \%$.

11.Guru dalam menciptakan suasana aktif belajar masih belum berjalan dengan baik, dengan prosentase sebesar $60 \%$ yang artinya Guru dalam menciptakan suasana aktif belajar tidak tuntas karena kurang dari $75 \%$.

12. Guru masih belum menyeluruh dalam membantu kesulitan belajar siswa, dengan prosentase sebesar $60 \%$ yang artinya Guru dalam Guru masih belum menyeluruh dalam membantu kesulitan belajar siswa tidak tuntas karena kurang dari $75 \%$.

13.Guru dalam membimbing siswa membuat presentasi sebesar $60 \%$ yang artinya keaktifan guru dalam membimbing siswa membuat presentasi tidak tuntas karena kurang dari $75 \%$.

14.Prosentase guru dalam membimbing siswa dalam membuat simpulan sebesar $60 \%$ yang artinya keaktifan guru dalam membimbing siswa membuat membimbing siswa dalam membuat simpulan tidak tuntas karena kurang dari $75 \%$.

15.Guru sudah baik dalam memberikan tugas dengan prosentase sebesar $80 \%$ yang artinya keaktifan guru dalam memberikan tugas tuntas karena lebih dari $75 \%$. 
16. Guru sudah baik dalam mengelola kelas, dengan prosentase sebesar $80 \%$ yang artinya keaktifan guru dalam mengelola kelas tuntas karena lebih dari $75 \%$.

17.Guru belum dapat mengelola waktu dengan baik karena prosentase kurang dari $75 \%$ yaitu sebesar $60 \%$.

18. Teknik bertanya guru kepada siswa masih belum baik yaitu sebesar $60 \%$ yang artinya teknik bertanya guru kepada siswa tidak tuntas karena kurang dari $75 \%$.

19.Prosentase skor keaktifan guru secara klasikal sebesar 67,5 \% yang artinya peran guru didalam kelas cukup baik.

Sedangkan hasil analisis dari lembar pengamatan siswa diperoleh hasil sebagai berikut :

1. Keaktifan siswa dalam mengikuti pelajaran sebesar $69,52 \%$ yang artinya indikator keaktifan siswa dikatakan tuntas karena lebih dari $65 \%$.

2. Kerjasama siswa dalam kelompok sebesar $68,57 \%$ yang artinya indikator kerjasama siswa dikatakan tuntas karena lebih dari $65 \%$.

3. Kesungguhan siswa dalam menyelesaikan tugas sebesar $69,52 \%$ yang artinya indikator kesungguhan siswa dalam menyelesaikan tugas dikatakan tuntas karena lebih dari $65 \%$.

4. Keberanian siswa dalam mempresentasikan hasil diskusi sebesar 59,04\% yang artinya indikator keberanian siswa dalam mempresentasikan hasil diskusi dikatakan tidak tuntas karena kurang dari $65 \%$.

5. Keaktifan siswa dalam bertanya sebesar 59,04 \% yang artinya indikator keaktifan siswa dalam bertanya dikatakan tidak tuntas karena kurang dari $65 \%$.

6. Keaktifan siswa dalam menyampaikan pendapat $60,92 \%$ yang artinya indikator keaktifan siswa dalam menyampaikan pendapat dikatakan tidak tuntas karena kurang dari $65 \%$.

7. Siswa yang tuntas dalam pembelajaran sebesar $47,61 \%$ yang artinya ketuntasan keaktifan siswa dalam mengikuti pembelajaran belum tercapai karena prosentase kurang dari $65 \%$.

8. Siswa yang tidak tuntas dalam pembelajaran sebesar $52,38 \%$.

Berdasarkan analisis hasil nilai ujian sebelum treatment dan sesudah treatment yaitu kegiatan pembelajaran dengan bantuan tutor sebaya, pada siklus I, dengan nilai rata-rata sebelum treatment adalah 44 sedangkan nilai rata-rata pada akhir siklus I adalah 58,85. Dari sini dapat kita lihat ada peningkatan sebesar 14,85. Dari akhir kegiatan pembelajaran pada siklus I juga didapat ketuntasan hasil belajar siswa secara klasikal sebesar 33,33\% yang artinya siswa yang masih belum tuntas sebesar $66,67 \%$. Prosentase peningkatan hasil belajar adalah $33,75 \%$.

Jika dilihat dari ketuntasan belajar siswa maka hasil belajar siswa dalam siklus I ini masih belum tercapai secara keseluruhan karena prosentase ketuntasan masih dibawah $\geq 75 \%$. Hal ini berarti hasil belajar siswa belum seperti yang diharapkan. Berdasarkan hasil pengamatan guru, hasil pengamatan siswa dan hasil belajar siswa maka dapat diketahui pada siklus I, indikator keberhasilan belum tercapai sehingga perlu diadakan tindakan perbaikan pada siklus II agar prestasi belajar siswa dapat ditingkatkan.

Dengan melihat hasil analisis hasil ujian sebelum treatment dan hasil ujian pada siklus I, dan melihat hasil refleksi dapat diketahui bahwa hasil belajar siswa masih belum sesuai harapan. Hal ini disebabkan karena dalam proses pembelajaran masih ada kekurangan yaitu dalam pengelolaan waktu, guru masih belum bisa membagi dengan baik sehingga pada saat memberikan penjelasan dan bimbingan terkesan tergesa-gesa akibatnya untuk siswa yang kemampuannya rendah semakin bingung.

Pengelolaan waktu yang tidak baik juga mengakibatkan guru tidak dapat membimbing siswa dengan baik dalam membuat simpulan. Disamping faktor diatas ada faktor lain yang menyebabkan proses pembelajaran tidak berjalan dengan lancar yaitu masih banyaknya siswa yang bicara sendiri pada saat kerja kelompok berlangsung, dan tutor sebaya yang masih belum mampu untuk memimpin kelompoknya, disamping itu juga peran tutor sebaya pada siklus I hanya membimbing anggota kelompoknya dalam mengerjakan soal-soal LKS sehingga pembelajaran dan kerjasama kelompok belum maksimal.

Pada pembelajaran yang dilakukan dengan tutor sebaya ini, siswa yang ditunjuk untuk menjadi tutor masih belum kelihatan keahliannya dalam membelajarkan materi kepada temannya. Disamping itu juga, pembelajaran tutor sebaya pada siklus I ini menggunakan pembelajaran tipe 
tutor to studentyang masih belum berjalan secara optimal. Dimana penerapan pada tipe ini adalah dalam satu kelompok yang dipimpin oleh seorang anak yang ditunjuk sebagai tutor memberikan bantuan kepada anggota kelompoknya dengan cara menyampaikan kembali materi yang sudah disampaikan oleh gurunya dengan bahasa tutor sendiri yaitu bahasa yang dimengerti oleh teman sebaya. Tugas tutor juga membantu siswa yang mengalami kesulitan dalam memahami persoalan yang diberikan oleh guru.. Karena pada pembelajaran siklus I ini kelas masih sangat ramai belum terkendali. Hal ini juga dikarenakan guru terlalu mengandalkan tutor dalam memegang peranan penting dalam pembelajaran. Sehingga kerjasama kelompok juga belum dapat berjalan dengan sangat baik. Padahal didalam pembelajaran tipe tutor to student ini diharapkan tutor dapat menjelaskan dan membimbing setiap anggota kelompoknya.

Berikut akan disajikan nilai siswa pada siklus II

Tabel 3 - Nilai Pada Siklus II

\begin{tabular}{cccc}
\hline Interval Nilai & Frekuensi & Predikat & Keterangan \\
\hline $88-100$ & 1 & A & Sangat baik \\
\hline $74-87$ & 9 & B & Baik \\
\hline $60-73$ & 11 & C & Cukup \\
\hline$<60$ & 0 & D & Kurang \\
\hline
\end{tabular}

Berdasarkan analisis lembar pengamatan guru, diperoleh hasil sebagai berikut:

1. Guru sudah baik dalam mempersiapkan kondisi siswa, begitu juga dalam penyampaian materi sehingga muncul respon positif dari siswa, dilihat dari antusias siswa yang bertanya dan menjawab pertanyaan.

2. Guru dalam memberikan bimbingan kepada tutor sebaya sebesar $100 \%$ yang artinya keaktifan guru dalam membimbing siswa tuntas karena lebih dari $75 \%$ sehingga mengalami peningkatan sebesar $20 \%$.

3. Guru dalam memberikan motivasi kepada tutor sebaya sebesar $100 \%$ yang artinya keaktifan guru dalam memotivasi tutor sebaya tuntas karena lebih dari $75 \%$ sehingga mengalami peningkatan sebesar $20 \%$.

4. Guru dalam memberikan motivasi siswa sebesar $100 \%$ yang artinya keaktifan guru dalam memotivasi siswa tuntas karena lebih dari $75 \%$ sehingga mengalami peningkatan sebesar $20 \%$.

5. Guru dalam memberi apersepsi sebesar $80 \%$ yang artinya keaktifan guru dalam memberi apersepsi tuntas karena lebih dari $75 \%$.

6. Guru mempersiapkan alat peraga dan media sebelum pembelajaran berlangsung sebesar $80 \%$ yang artinya keaktifan guru dalam mempersiapkan alat peraga dan media sebelum pembelajaran berlangsung tuntas karena lebih dari $75 \%$ sehingga mengalami peningkatan sebesar $20 \%$

7. Guru dalam mengelompokkan siswa sudah teratur dengan prosentase sebesar $80 \%$ yang artinya keaktifan guru dalam mengelompokkan siswa tuntas karena lebih dari $75 \%$ sehingga mengalami peningkatan sebesar $20 \%$.

8. Guru sudah berperan dalam memotivasi siswa tentang pentingnya kerjasama dalam kelompok yaitu sebesar $80 \%$ yang artinya keaktifan guru dalam dalam memotivasi siswa tentang pentingnya kerjasama dalam kelompok tuntas karena lebih dari $75 \%$ sehingga mengalami peningkatan sebesar $20 \%$.

9. Peran guru sebagai fasilitator sebesar $100 \%$ yang artinya peran guru sebagai fasilitator tuntas karena lebih dari $75 \%$ sehingga mengalami peningkatan sebesar $40 \%$.

10.Guru dalam menciptakan suasana aktif belajar sudah berjalan dengan baik, dengan prosentase sebesar $100 \%$ yang artinya Guru dalam menciptakan suasana aktif belajar tuntas karena lebih dari $75 \%$ sehingga mengalami peningkatan sebesar $40 \%$.

11. Guru sudah menyeluruh dalam membantu kesulitan belajar siswa, dengan prosentase sebesar $100 \%$ yang artinya Guru sudah menyeluruh dalam membantu kesulitan belajar siswa dikatakan tuntas karena lebih dari $75 \%$ sehingga mengalami peningkatan sebesar $40 \%$.

12. Guru dalam membimbing siswa membuat presentasi sebesar $100 \%$ yang artinya keaktifan guru dalam membimbing siswa membuat presentasi tuntas karena lebih dari $75 \%$ sehingga mengalami peningkatan sebesar $40 \%$. 
13.Prosentase guru dalam membimbing siswa dalam membuat simpulan sebesar $100 \%$ yang artinya keaktifan guru dalam membimbing siswa membuat simpulan tuntas karena lebih dari 75 $\%$ sehingga mengalami peningkatan sebesar $40 \%$.

14.Guru sudah baik dalam memberikan tugas dengan prosentase sebesar $100 \%$ yang artinya keaktifan guru dalam memberikan tugas tuntas karena lebih dari $75 \%$ sehingga mengalami peningkatan sebesar $40 \%$.

15. Guru sudah baik dalam mengelola kelas, dengan prosentase sebesar $80 \%$ yang artinya keaktifan guru dalam mengelola kelas tuntas karena lebih dari $75 \%$.

16.Guru sudah dapat mengelola waktu dengan baik karena prosentase lebih dari $75 \%$ yaitu sebesar $80 \%$ yang artinya guru dalam mengelola waktu tuntas sehingga mengalami peningkatan sebesar $20 \%$.

17.Teknik bertanya guru kepada siswa sudah baik yaitu sebesar $80 \%$ yang artinya teknik bertanya guru kepada siswa tuntas karena kurang dari $75 \%$ sehingga mengalami peningkatan sebesar 20 $\%$.

18.Prosentase skor secara keseluruhan sebesar $91,25 \%$ yang artinya peran guru didalam kelas amat baik. berikut :

Sedangkan hasil analisis berdasarkan lembar pengamatan siswa diperoleh hasil sebagai

1. Keaktifan siswa dalam mengikuti pelajaran sebesar $76,19 \%$ mengalami peningkatan sebesar $11,43 \%$ yang artinya indikator keaktifan siswa dapat tercapai karena diatas $65 \%$.

2. Kerjasama siswa dalam kelompok sebesar $77,14 \%$ mengalami peningkatan sebesar $8,57 \%$ yang artinya indikator keaktifan siswa dalam bekerjasama dengan kelompok dapat tercapai karena diatas $65 \%$.

3. Kesungguhan siswa dalam menyelesaikan tugas sebesar $80,95 \%$ mengalami peningkatan sebesar $11,43 \%$ yang artinya indikator keaktifan siswa dalam menyelesaikan tugas dapat tercapai karena diatas $65 \%$.

4. Keberanian siswa dalam mempresentasikan hasil diskusi sebesar $70,47 \%$ mengalami peningkatan sebesar $11,43 \%$ yang artinya indikator keaktifan siswa dalam mempresentasikan hasil diskusi dapat tercapai karena diatas $65 \%$.

5. Keaktifan siswa dalam bertanya sebesar $63,80 \%$ mengalami peningkatan sebesar 4,76 \% yang artinya indikator keaktifan siswa dalam bertanya belum tercapai karena dibawah $65 \%$.

6. Keaktifan siswa dalam menyampaikan pendapat $63,80 \%$ mengalami peningkatan sebesar 2,88 $\%$ yang artinya indikator keaktifan siswa dalam menyampaikan pendapat belum tercapai karena dibawah $65 \%$.

7. Keaktifan siswa yang tuntas dalam pembelajaran sebesar $80,95 \%$ mengalami peningkatan sebesar 33,34 \%.

8. Siswa yang tidak tuntas dalam pembelajaran sebesar $19,04 \%$ dan mengalami penurunan sebesar $33,34 \%$.

Berdasarkan analisis hasil nilai ujian pada akhir siklus I nilai rata-ratanya adalah 58,85 sedangkan nilai rata-rata pada akhir siklus II adalah 74,47. Ketuntasan belajar siswa secara klasikal sebesar 80,95\% yang artinya mengalami peningkatan sebesar 47,62 \%. Prosentase peningkatan hasil belajar adalah $26,54 \%$. Hal ini berarti hasil belajar siswa sudah tercapai seperti yang diharapkan.

Berdasarkan hasil pengamatan guru, hasil pengamatan siswa dan hasil belajar siswa pada siklus II maka dapat diketahui bahwa indikator keberhasilan sudah tercapai sehingga prestasi belajar siswa dapat meningkat dengan pembelajaran tutor sebaya. Dengan melihat hasil yang sudah dicapai pada siklus II dan hasil refleksi dapat diketahui bahwa hasil belajar siswa sudah sesuai yang diharapkan. Hal ini disebabkan karena dalam proses pembelajaran adanya peran guru dan keaktifan siswa yang lebih baik dibandingkan dengan proses pembelajaran pada siklus I.

Pengelolaan waktu yang baik membuat guru dapat membimbing siswa dalam membuat simpulan dengan baik. Guru sudah membantu siswa-siswi yang memang mengalami kesulitan dalam proses pembelajaran. Disamping itu juga peran tutor sebaya di dalam kelompoknya sudah dapat terlihat. 
Pembelajaran yang menggunakan pembelajaran tutor dengan tipe tutor to student ini dapat berjalan secara optimal. Peran tutor sudah dapat terlihat dengan baik. Keahlian tutor dalam menjelaskan materi dan membimbing temannya sudah dapat terllihat dengan baik. Tutor sebaya dapat membimbing anggota kelompoknya tanpa ada perasaan canggung lagi, tutor sebaya tidak hanya membimbing siswa dalam mengerjakan soal-soal pada LKS tetapi tutor sebaya mampu untuk menjelaskan materi kembali kepada anggota-anggota kelompoknya. Anggota kelompok yang bukan merupakan tutor juga sudah tidak merasa malu lagi dalam bertanya dan mengutarakan pendapat dengan tutornya. Kerjasama kelompok dapat berjalan dengan baik karena dukungan dari guru, tutor, maupun siswa yang tidak menjadi tutor.

Sehingga pada siklus II ini, prestasi belajar siswa dapat meningkat dengan bantuan tutor sebaya dengan nilai rata-rata sebesar 74,47 sehingga mengalami peningkatan sebesar 47,62 \% . Hal ini sudah dikatakan berhasil karena ketuntasan hasil belajar secara klasikal sebesar 80,95 \% yang artinya mengalami peningkatan sebesar 47,62 \%diatas indikator yang sudah ditetapkan, yaitu sebesar 75\%. Dengan prosentase keaktifan siswa secara klasikal sebesar 80,95 \% dan keaktifan guru sebesar $91,25 \%$ sehingga dapat dikatakan hasil belajar pada pembelajaran siklus II dapat meningkat sesuai dengan indikator yang sudah ditetapkan.

Berikut ini akan disajikan tabel pencapaian hasil belajar siswa, hasil pengamatan Guru, dan pengamatan terhadap siswa.

Tabel 4 - Pencapaian tiap Indikator Tiap Siklus

\begin{tabular}{ccc}
\hline Indikator Keberhasilan & Siklus I & Siklus II \\
\hline Nilai rata-rata & 58,85 & 74,47 \\
\hline Keaktifan Guru & $67,5 \%$ & $91,25 \%$ \\
\hline Keaktifan siswa klasikal & $47,61 \%$ & $80,95 \%$ \\
\hline Ketuntasan Belajar klasikal & $33,33 \%$ & $80,95 \%$ \\
\hline
\end{tabular}

Tabel 5 - Pencapaian tiap Indikator Pengamatan Guru Tiap Siklus

\begin{tabular}{cccc}
\hline NO & ASPEK YANG DIAMATI & $\begin{array}{c}\text { SIKLUS I } \\
(\boldsymbol{\%})\end{array}$ & $\begin{array}{c}\text { SIKLUS II } \\
(\boldsymbol{\%})\end{array}$ \\
\hline 1 & Memberi bimbingan tutor sebaya & 80 & 100 \\
\hline 2 & Memberi motivasi tutor sebaya & 80 & 100 \\
\hline 3 & Memberi motivasi siswa & 80 & 100 \\
\hline 4 & Memberi apersepsi & 80 & 80 \\
\hline 5 & Persiapan alat dan media pembelajaran yang diperlukan & 60 & 80 \\
\hline 6 & Mengelompokkan siswa & 60 & 80 \\
\hline 7 & Memotivasi siswa tentang pentingnya kerjasama dalam kelompok & 60 & 80 \\
\hline 8 & Berperan sebagai fasilitator & 60 & 100 \\
\hline 9 & Menciptakan suasana aktif belajar & 60 & 100 \\
\hline 10 & Membantu kesulitan belajar siswa & 60 & 100 \\
\hline 11 & Membimbing siswa dalam membuat presentasi. & 60 & 100 \\
\hline 12 & Membimbing siswa dalam membuat simpulan & 60 & 100 \\
\hline 13 & Memberikan tugas & 80 & 100 \\
\hline 14 & Pengelolaan kelas. & 80 & 80 \\
\hline 15 & Pengelolaan waktu & 60 & 80 \\
\hline 16 & Teknik bertanya. & 60 & 80 \\
\hline
\end{tabular}

Tabel 6 - Pencapaian Pengamatan Keaktifan Tiap Siswa

\begin{tabular}{|c|c|c|c|c|c|c|c|}
\hline \multirow{2}{*}{ No } & \multirow{2}{*}{ Nama } & \multirow{2}{*}{$\begin{array}{c}\text { Siklus I } \\
(\%)\end{array}$} & \multicolumn{2}{|c|}{ Ketuntasan } & \multirow{2}{*}{$\begin{array}{c}\text { Siklus II } \\
(\%)\end{array}$} & \multicolumn{2}{|c|}{ Ketuntasan } \\
\hline & & & $\mathbf{T}$ & TT & & $\mathbf{T}$ & TT \\
\hline 1 & A & 63,33 & & $\mathrm{~V}$ & 80 & $\mathrm{~V}$ & \\
\hline 2 & $\mathrm{~B}$ & 53,33 & & $\mathrm{~V}$ & 70 & V & \\
\hline 3 & $\mathrm{C}$ & 66,67 & $\mathrm{~V}$ & & 83,33 & $\mathrm{~V}$ & \\
\hline 4 & $\mathrm{D}$ & 70 & $\mathrm{~V}$ & & 90 & $\mathrm{~V}$ & \\
\hline 5 & $\mathrm{E}$ & 63,33 & & $\mathrm{~V}$ & 66,67 & $\mathrm{~V}$ & \\
\hline 6 & $\mathrm{~F}$ & 76,67 & $\mathrm{~V}$ & & 93,33 & $\mathrm{~V}$ & \\
\hline 7 & $\mathrm{G}$ & 66,67 & $\mathrm{~V}$ & & 76,67 & $\mathrm{~V}$ & \\
\hline 8 & $\mathrm{H}$ & 70 & V & & 73,33 & V & \\
\hline
\end{tabular}




\begin{tabular}{|c|c|c|c|c|c|c|c|}
\hline \multirow{2}{*}{ No } & \multirow{2}{*}{ Nama } & \multirow{2}{*}{$\begin{array}{c}\text { Siklus I } \\
(\%)\end{array}$} & \multicolumn{2}{|c|}{ Ketuntasan } & \multirow{2}{*}{$\begin{array}{c}\text { Siklus II } \\
(\%)\end{array}$} & \multicolumn{2}{|c|}{ Ketuntasan } \\
\hline & & & $\mathbf{T}$ & TT & & $\mathbf{T}$ & TT \\
\hline 9 & $\mathrm{I}$ & 70 & $\mathrm{~V}$ & & 66,67 & $\mathrm{~V}$ & \\
\hline 10 & $\mathrm{~J}$ & 60 & & $\mathrm{~V}$ & 60 & & $\mathrm{~V}$ \\
\hline 11 & $\mathrm{~K}$ & 60 & & $\mathrm{~V}$ & 66,67 & $\mathrm{~V}$ & \\
\hline 12 & $\mathrm{~L}$ & 73,33 & $\mathrm{~V}$ & & 80 & $\mathrm{~V}$ & \\
\hline 13 & $\mathrm{M}$ & 63,33 & & $\mathrm{~V}$ & 60 & & V \\
\hline 14 & $\mathrm{~N}$ & 66,67 & $\mathrm{~V}$ & & 70 & V & \\
\hline 15 & $\mathrm{O}$ & 63,33 & & $\mathrm{~V}$ & 66,67 & $\mathrm{~V}$ & \\
\hline 16 & $\mathrm{P}$ & 66,67 & $\mathrm{~V}$ & & 73,33 & $\mathrm{~V}$ & \\
\hline 17 & Q & 53,33 & & $\mathrm{~V}$ & 60 & & $\mathrm{~V}$ \\
\hline 18 & $\mathrm{R}$ & 56,67 & & $\mathrm{~V}$ & 70 & $\mathrm{~V}$ & \\
\hline 19 & $\mathrm{~S}$ & 50 & & $\mathrm{~V}$ & 66,67 & $\mathrm{~V}$ & \\
\hline 20 & $\mathrm{~T}$ & 50 & & $\mathrm{~V}$ & 63,33 & & $\mathrm{~V}$ \\
\hline 21 & $\mathrm{U}$ & 83,33 & $\mathrm{~V}$ & & 93,33 & $\mathrm{~V}$ & \\
\hline
\end{tabular}

Tabel 7 - Pencapaian Pengamatan Keaktifan Tiap Siswa

\begin{tabular}{cccc}
\hline No & Aspek yang Diamati & $\begin{array}{c}\text { Siklus I } \\
(\%)\end{array}$ & $\begin{array}{c}\text { Siklus II } \\
(\%)\end{array}$ \\
\hline 1 & Keaktifan siswa dalam mengikuti pelajaran & 69,52 & 76,19 \\
\hline 2 & Kerjasama siswa dalam kelompok & 68,57 & 77,14 \\
\hline 3 & Kesungguhan siswa dalam menyelesaikan tugas & 69,52 & 80,95 \\
\hline 4 & Keberanian siswa dalam mempresentasikan hasil diskusi & 59,04 & 70,47 \\
\hline 5 & Keaktifan siswa dalam bertanya & 59,04 & 63,80 \\
\hline 6 & Keaktifan siswa dalam menyampaikan pendapat & 60,92 & 63,80 \\
\hline
\end{tabular}

\section{KESIMPULAN}

Berdasarkan hasil penelitian dan pembahasan dapat disimpulkan bahwa melaui strategi pembelajaran dengan tutor sebaya dapat meningkatkan prestasi belajar siswa kelas VI SD HIDAYATUR ROHMAN Surabaya tahun ajaran 2016-2017 dalam menyelesaikan soal-soal pada materi pokok Bangun Datar.

\section{DAFTAR RUJUKAN}

Arikunto, Suharsimi. (2006). Prosedur Penelitian. Jakarta: Rineka Cipta

Aqib, Zainal,dkk. (2008). Penelitian Tindakan Kelas untuk Guru SMP, SMA, SMK. Bandung: Yrama Widya

Cholik \& Sugijono. 2005. Matematika untuk SMP Kelas VIII (edisi kedua). Jakarta: Erlangga

Darmansyah. (2010). Strategi Pembelajaran Menyenangkan dengan Humor. Jakarta: Bumi Aksara Dimyati \& Mudjiono. 2006. Belajar dan Pembelajaran. Jakarta: Rineka Cipta

Djamarah, Syaiful Bahri \& Zain, Aswan. (2006). Strategi Belajar Mengajar. Jakarta: Rineka Cipta

Djamarah, Syaiful Bahri \& Zain, Aswan. (2010). Strategi Belajar Mengajar edisi revisi. Jakarta: Rineka Cipta

Ekawarna. 2009. Penelitian Tindakan Kelas. Jakarta: Gaung Persada

Fathurrohman, Pupuh \& Sutikno, Sobry. (2007). Strategi Belajar Mengajar Melalui Penanaman Konsep Umum dan Konsep Islami. Bandung: PT. Refika Aditama

Mursyidah, Cicik. (2005). Studi Perbandingan Prestasi Belajar Matematika Pokok Bahasan Himpunan Antara Siswa yang Belajar Kelompok dengan Siswa yang Belajar Perorangan di Kelas 1 Semester Gasal MTs. Negeri Krian Sidoarjo Tahun Pelajaran 2003/2004. Skripsi yang tidak dipublikasikan. Surabaya: Program Sarjana Universitas Wijaya Kusuma

Sari, Ika Marlita. (2006). Keefektifan Model Pembelajaran Tutor Sebaya Terhadap Hasil Belajar Matematika Pokok Bahasan Persamaan Garis Lurus Siswa Kelas VIII SMP Negeri 36 Semarang. Skripsi yang tidak dipublikasikan. Semarang: Program Sarjana Universitas Negeri Semarang 
Silberman, Melvin L. (2010). Active Learning 101 Cara Belajar Siswa Aktif (edisi revisi). Bandung: Nusamedia

Suherman, Erman. (2001). Strategi Pembelajaran Matematika Kontemporer. Jakarta: Universitas Pendidikan Indonesia

Supriyanto, Agung. (2007). Meningkatkan Hasil Belajar Siswa Kelas VIII A SMP I Kaliwangu Kudus Tahun Pelajaran 2006-2007 Dalam Meyelesaikan Soal-Soal pada materi Pokok Sistem Persamaan Linier Dua Variabel Melalui Implementasi Pembelajaran Kooperatif dengan Tutor Sebaya. Skripsi yang tidak dipublikasikan. Semarang: Program Sarjana Universitas Negeri Semarang

Tim. (2007). Kamus Besar Bahasa Indonesia. Jakarta: Balai Pustaka

Trianto. (2007). Model - Model Pembelajaran Inovatif Berorientasi Konstruktivistik. Jakarta: Prestasi Pustaka

Zaini, Hisyam,dkk. 2008. Strategi Pembelajaran Aktif. Yogyakarta: Pustaka Insan Madani 